\title{
Litterfall, precipitation and nutrient fluxes in a secondary lowland rain forest in Ile-Ife, Nigeria
}

\author{
Modupe B. Oziegbe ${ }^{1,2}$, Joseph I. Muoghalu ${ }^{1}$ and Samson O. Oke ${ }^{1}$
}

Recebido em 23/01/2011. Aceito em 29/06/2011

\begin{abstract}
RESUMO
(Queda de serrapilheira, precipitação e fluxo de nutrientes em uma floresta pluvial secundária de terras baixas em Il-Ife, Nigéria) Produção de serapilheira, precipitação e o fluxo de nutrientes foram investigados em uma parcela de 0,25 ha de uma floresta pluvial secundária de terras baixas em Ile-Ife, Nigéria, por um período de um ano. O estudo determinou a magnitude dos fluxos de nutrientes através da serrapilheira, da chuva incidente, da interceptada, da escoada pelo tronco, e também avaliou a importância relativa desses componentes como vias de transporte de nutrientes para o solo desta floresta. Houve variação mensal significativa na produção e acúmulo de serapilheira com maiores valores ocorrendo de novembro a março. A concentração de elementos em tanto na chuva interceptada como na escoada pelo tronco foram maiores que na chuva incidente. Maiores quantidades de cálcio, magnésio, ferro, cobre, zinco e nitrogênio foram depositados anualmente a partir da serrapilheira no chão da floresta, enquanto maiores quantidades de mercúrio, potássio, sódio, fósforo, chumbo e enxofre foram depositados através de precipitação. Ocorreu lixiviação de todos os elementos pela passagem da precipitação pelo dossel com a exceção de cobre, íons de hidrogênio, e chumbo, que foram retidos no dossel. Como conclusão este estudo mostra que a serapilheira é a principal via para a ciclagem de cálcio, magnésio, nitrogênio e todos micronutrientes investigados. A precipitação é o principal via para a ciclagem de potássio, fósforo, enxofre e traços de metais tóxicos (mercúrio e chumbo) na floresta.
\end{abstract}

Palavras-chave: deposição de nutrientes, as chuvas, lixo, solo, floresta secundária

\begin{abstract}
(Litterfall, precipitation and nutrient fluxes in a secondary lowland rain forest in Ile-Ife, Nigeria). Litterfall, precipitation and nutrient fluxes were investigated in a 0.25 ha plot of a secondary lowland rain forest in Ile-Ife, Nigeria, for a period of one year. The study determined the magnitude of nutrient fluxes through (litterfall, incident rainfall, throughfall and stemflow) and evaluated the relative importance of these components as pathways of nutrient transport to the soil of this forest. There was a significant monthly variation in litterfall and the highest values of the standing crop of litter occurred from November to March. The concentration of elements in both throughfall and stemflow were higher than those of incidence rainfall. Greater quantities of calcium, magnesium, iron, zinc, copper and nitrogen were deposited annually from the forest floor while greater quantities of mercury, potassium, sodium, phosphorus, lead and sulphur were deposited via precipitation. There was net leaching of all elements from the canopy as precipitation pass through it with the exception of copper, hydrogen ions and lead, which were retained in the canopy. The finding of this study shows that litterfall is the major pathway for the cycling of calcium, magnesium, nitrogen and all micronutrients investigated. Net precipitation is the major pathway for the cycling of potassium, phosphorus, sulphur and trace toxic metals (mercury and lead) in the forest.
\end{abstract}

Key words: Nutrient deposition, rainfall, litter, soil, secondary forest

\section{Introduction}

An understanding of nutrient cycle processes is fundamental to the management of natural and disturbed vegetation growing on tropical soils of low fertility (Congdon \& Herborn 1993). Nutrient cycles are important ecological processes, which involve the cycling of elements through the biotic and geochemical components of the ecosystems.
Like the hydrological cycle and energy flow, nutrient cycles are essential for all ecosystems to function. Brasel for all ecosystems to function, Brasell et al. (1980) report that the turnover rate of nutrients is one of the main important factors for the functioning and stability of ecosystems (Congdon \& Herborn 1993). Nutrient flux is a term used by several authors (Carlisle et al. 1966; Gosz et al. 1976; Parker 1983) to describe nutrient transfer by various pathways.

\footnotetext{
${ }^{1}$ Department of Botany, Obafemi Awolowo University, Ile-Ife, Nigeria

${ }^{2}$ Author for correspondence: ibidunesan@yahoo.com
} 
Litterfall, throughfall and stemflow are the main fluxes through which nutrients move from the vegetation to the soil surface (Herborn \& Congdon 1998). Nutrients are primarily transferred through falling leaves and plant parts as litter, where percolating water subsequently leach them and they are decomposed by organisms (Eaton et al. 1973). Litterfall is significant because it is the means by which the litter layer on the forest floor is formed and is described as the third major pool of nutrients in the biogeochemical cycles (Congdon \& Lamb 1990). Above-ground litter is a major pathway linking the plant component to the soil in an ecosystem through organic matter decomposition (Arunachalam et al. 1998). Litterfall and its decomposition processes maintain nutrient pools in the soil, influence primary production and regulate energy flow and nutrient cycling in forest ecosystem (Waring \& Scheslinger 1985). Analysis of element concentrations in litterfall can be used to give an indication of limiting nutrients and nutrient use efficiency in forests (Vitousek 1982; Proctor et al. 1983).

A significant amount of nutrients is also transferred from the atmosphere and various plant parts to the forest ecosystem as rain falls and passes through the forest canopy (Parker 1983). Incident precipitation is described as water that falls on the forest directly (Parker 1983). It is also referred to as gross fall (Lindberg et al. 1979) and most times, the incident precipitation is often intercepted by the canopy (Kittredge 1948). Throughfall refers to the precipitation which passes through the canopy and falls to the ground. This process can be responsible for leaching nutrients from canopy leaves and transporting them to the forest floor (Parker 1983). In some particular cases, throughfall may exceed incident precipitation in quantity, e.g., under fog precipitation (Zinke 1962; Banaszak 1975; Prebble \& Stirk 1980). Throughfall includes incident precipitation which penetrates canopy gaps unless the individual canopy gaps are large and frequent (Parker 1983). Another additional portion of precipitation, stemflow, reaches the ground by running down the branches and trunks, and is deposited at the base of the tree (Parker 1983). Throughfall and stemflow involve the transfer of nutrient elements from the forest canopy directly to the available nutrient pool without the intervention of any process of decomposition on the forest floor (Eaton at al. 1973). Further, precipitation that drips from the foliage or runs down the boles of tree may be substantially enriched in nutrients (Pathak \& Singh 1984; Liu et al. 2002). Estimation of the fluxes of elements from incident precipitation, throughfall and stemflow has been a routine part of nutrient budget studies in temperate forests for quite some time (Likens et al. 1977; Schlensinger 1978; Sollin et al. 1980). However corresponding studies in tropical rain forest areas are comparatively rare. In addition, these studies have mostly focused on throughfall only (Brinkmann 1985; Sinun et al. 1992; Burghouts et al. 1998), particularly for secondary growth forests ( Bruijinzeel 1983; Muoghalu \& Oakumen 2000).
Nutrient cycling rates in forests are usually inferred from the comparison of nutrient concentrations and amounts in litterfall, forest floor litter and crown drip (Vitousek \& Sanford 1986; Proctor et al. 1983). Estimates suggest that approximately $30 \%$ of all productive tropical forest land is covered in secondary forest (Brown \& Lugo 1990). Little is known about the basic ecological processes that influence nutrient cycling during secondary forest succession. This study examined the magnitude of nutrient fluxes through litterfall, incident rainfall, throughfall and stemflow, and evaluated the relative importance of these components as pathways of nutrient transport to the soil of the forest studied.

\section{Materials and methods}

\section{Study area}

The study site is located within the Biological Gardens of Obafemi Awolowo University, Ile-Ife, Nigeria. Ile-Ife lies within latitudes $7^{\circ} 30^{\prime} \mathrm{N}$ to $7^{\circ} 35^{\prime} \mathrm{N}$ and longitudes $4^{\circ} 30^{\prime}$ to $4^{\circ} 35^{\prime} \mathrm{E}$. The elevation of the area is $215 \mathrm{~m}$ (at the bottom of the hills) to $457 \mathrm{~m}$ (on the top of the hills) above mean sea level (a.s.l) (Hall 1969). There are three inselbergs formed as a result of uneven weathering of parent rocks known as Hills I, II and III at different parts of the campus. The three inselbergs have plant communities ranging from forest vegetation at their base and lower slopes, savanna vegetation on the upper slopes and isolated ephemeral vegetation mats on the peaks. Twenty litter sample plots each of, $25 \mathrm{mx} 25 \mathrm{~m}$, were established in a secondary forest with 59 -years of regrowth at the base $(300 \mathrm{~m}$ a.s.l). There are two prominent seasons in the Ife area, the rainy season (March-November) and the dry season (November-March). The annual rainfall averaged $1413 \mathrm{~mm}$ per year in a 5-year survey (Duncan 1974), with two peaks, one in July and the other in September. The monthly humidity is $58.1 \%$ and at 10:00 h relative humidity is $82.8 \%$. The temperature ranges between $22.5-31.4^{\circ} \mathrm{C}$ (Duncan 1974). In our study, monthly mean maximum temperatures were $33.80^{\circ} \mathrm{C}$ and $31.6^{\circ} \mathrm{C}$ and minimum temperatures were $22.5^{\circ} \mathrm{C}$ and $21.9^{\circ} \mathrm{C}$ in 2001 and 2002, respectively. Onochie (1979) reported that Ile-Ife area lies in a dry deciduous forest zone. White (1983) also described the vegetation as Guineo-Congolian drier type. The basal area of trees in the forest was $32.2 \mathrm{~m}^{2} \mathrm{ha}^{-1}$ and stem density of woody plants less than $2 \mathrm{~m}$ in height was 798 plants per 0.25 ha (Isichei et al. 1986). The eleven most abundant species are Albizia zygea, Blighia unijugata, Bombax buonopozense, Bosqueia angolensis, Commiphora kerstingii, Elaeis guineensis, Ficus mucoso, Funtumia elastica, Holarrhena floribunda, Manihot glaziovii and Pycnanthus angolensis (Isichei et al. 1986). The most frequently occurring plant families are Apocynanceae, Euphorbiaceae, Mimosaceae, Moraceae, Rubiaceae and Sapindaceae. The percentage canopy cover in the study plot is $88.8 \pm 0.8 \%$ (Awokoya 2003). 
The area is underlain by rocks of the Basement Complex, which are of Precambrian age (Wilson 1922). The Basement complex consists of heterogeneous group of rocks (gneisses, schists, granites and minor rocks types such as pegmatites). The soils are Luxisols (FAO/UNESCO 1974) and Ultisols (USDA 1975). The soil temperature regime is Isohyperthermic, the soil moisture is ustic and clay minerals are mostly kaolinite. The soils of the area are moderately to strongly leached and have low to medium humus content, weakly acid to neutral surface layers and moderately to strong acid sub soils (Ayodele 1986).

\section{Sampling procedure}

Litterfall and litter standing crop. Litterfall and litter standing crop were determined on a monthly basis for a period of one year (from November 2001 to October 2002). In the sample plot, twenty $1 \mathrm{~m} \mathrm{x} 1 \mathrm{~m}$ x $30 \mathrm{~cm}$ quadrat litter traps raised $1 \mathrm{~m}$ above the ground were randomly located. Litter traps were emptied monthly. The litter was sorted into four fractions (1) leaf (2) wood (3) reproductive parts (flower, fruits and seeds) and (4) trash. All fractions were weighed separately. Five (5) $50 \mathrm{~cm}$ by $50 \mathrm{~cm}$ quadrats were randomly laid in the litter layer on the plot (monthly) for a period of one year to collect the litter standing crop. The litter standing crop within each quadrat was collected, sorted into leaf, wood, reproductive parts and trash. The litter standing crop was collected the same day and the same time the litter traps were emptied. The positions of the sample collections were marked after sampling to avoid resampling. The collected litters, both litterfall and litter standing crop, were oven dried at $80^{\circ} \mathrm{C}$ to a constant weight and weighed within a precision scale.

After determining the dry weights of all fractions for individual traps and litter standing crop, the oven dried samples of all litter components (leaf, wood, reproductive parts and trash) were bulked into one sample for each month and ground for chemical analyses. The weights were used to calculate monthly litterfall and litter standing crop and total nutrient content.

\section{Precipitation}

Precipitation in this study was restricted to three different fractions: incident precipitation, throughfall and stemflow. Sample collection was carried out during the 2002 rainy season (March-November). Incident precipitation was sampled in an open area, $150 \mathrm{~m}$ from the forest using a glass rainfall collector equipped with a sharp rimmed glass funnel (20 cm diameter), mounted on a support $1.5 \mathrm{~m}$ above the ground, to collect incident precipitation. The funnel of the collector was fitted with a plastic-screen of $1 \mathrm{~mm}$ mesh to trap coarse debris (small insects, animals and litterfall). Throughfall was sampled by placing 20 polyethylene collectors each fitted with a polyethylene funnel $(19.8 \mathrm{~cm}$ diameter) raised $1.5 \mathrm{~m}$ above the ground level under the crowns of randomly selected trees. The funnels were fitted with the plastic screens of $1 \mathrm{~mm}$ mesh size to trap coarse debris. Stemflow was sampled using stem collars (plastic tubing) fitted at breast height on the stems of 15 randomly selected trees used for the throughfall study. The stem collars were connected to polyethylene containers to receive the stemflow.

All rainwater fractions were collected within 24 hours after each rainfall event. The funnel and containers were washed and rinsed with distilled water before being replaced after each collection. Volumes of the different rainfall fractions (incident rainfall, throughfall and stemflow) were measured using measuring cylinders. The samples were filtered through No 44 Whatman filter paper. Sub-samples $(200 \mathrm{~mL})$, or less depending on the volume of the rainwater, were taken after each rainfall event and stored in plastic bottles at $4{ }^{\circ} \mathrm{C}$ in a refrigerator for chemical analysis. Composite samples from each rainwater fraction containing all subsamples of all rainfall events in a month were used for the chemical analysis.

\section{Chemical analysis}

Ground litter samples were digested using mixed acid (nitric-perchloric-sulphuric) procedures of Allen $e t$ al. (1974). A $0.2 \mathrm{~g}$ sub-sample of each ground sample was digested in $7.0 \mathrm{~mL}$ of the digestion mixture. These digested samples were analysed for potassium, sodium, calcium, magnesium, manganese, zinc, copper, iron, lead, and mercury with an atomic absorption spectrophotometer (Alpha Model 4). Total nitrogen and phosphorus concentrations of the ground samples were determined at the International Institute of Tropical Agriculture (IITA), Ibadan, according to the method of Tel \& Rao (1982). Total sulphur was determined by the turbidometric spectrophotometric method using $\mathrm{BaCl}_{2}$ crystals as the precipitating agent and $0.25 \%$ of gum acacia as the stabilizer (Allen et al. 1974). The rainwater samples were analysed for potassium, sodium, calcium, magnesium, manganese, zinc, copper, iron, lead, mercury, nitrate-nitrogen $\left(\mathrm{NO}_{3}^{-} \mathrm{N}\right)$, phosphate-phosphorus $\left(\mathrm{PO}_{4}^{3-}-\mathrm{P}\right)$, sulphate-sulphur $\left(\mathrm{SO}_{4}^{2-}-\mathrm{S}\right)$. The cations were determined directly from the water samples using an atomic absorption spectrophotometer (Alpha model 4). Nitratenitrogen and phosphate-phosphorus was determined with a Techicon Auto analyzer using Standard Technicon procedures at the International Institute of Tropical Agriculture, (IITA), Ibadan. Sulphate-sulphur was determined by the turbidometric spectrophotometric method using $\mathrm{BaCl}_{2}$ crystals as the precipitating agent and $0.25 \%$ gum acacia as the stabilizer (Moore \& Chapman 1986).

\section{Statistical analysis}

A two-way analysis of variance was used to evaluate significant differences of monthly element concentration, amount of elements and fractions of standing crop of litter, with months and fractions as factors (Zar 1984). Repeated measures design of analysis of variance was used to test 
significance differences in the monthly concentration of elements and amounts deposited via the litterfall and precipitation components because the locations of sampling positions were random but monthly collections were not repositioned each month. The tests were performed using system analysis software version 8.0 (SAS 1999).

\section{Results}

Litterfall, litter standing crop and precipitation - the annual litterfall $\left(\mathrm{kg} \mathrm{ha}^{-1} \mathrm{yr}^{-1}\right)$ in the plot was 9325 (total); 7034.4 (leaf); 1360.5 (wood); 83.6 (reproductive parts) and 846.5 (trash). The relative contribution of various litter components to the total litterfall in the plot shows that the leaf litterfall contributed the highest proportion (75.5\%), followed by wood (14.6\%), trash (9.1\%), reproductive parts (0.9\%). There was continuous litterfall throughout the year. All litterfall components, leaf ( $p<0.05)$, wood $(\mathrm{p}<0.05)$, reproductive parts $(\mathrm{p}<0.05)$, trash $(\mathrm{p}<0.05)$, showed significant monthly variation.

The annual standing litter crop of litter $\left(\mathrm{kg} \mathrm{ha}^{-1}\right)$ in the plot was 3631.4 (total), 2064.5 (leaf), 1062.8 (wood), 42.2 (reproductive parts) and 461.9 (trash). The relative contributions of various litter components to the standing litter crop were leaf (56.8\%), wood (29.3\%), trash (12.7\%) and reproductive parts $(1.2 \%)$. These values are higher than those of the components of litterfall with the exception of that of leaf litterfall. All standing crop of litter components, leaf $(\mathrm{p}<0.05)$, wood $(\mathrm{p}<0.05)$, reproductive parts $(\mathrm{p}<0.05)$ and trash $(\mathrm{p}<0.05)$, showed significant monthly variation.

The gross annual rainfall in the open area was 1079.6 $\mathrm{mm}$. In the secondary rainforest, throughfall was 831.7 $\mathrm{mm}(77.0 \%)$, stemflow $70.6 \mathrm{~mm}(6.5 \%)$ and canopy interception $177.49 \mathrm{~mm}(16.4 \%)$ of the gross annual rainfall. In the open area about $150 \mathrm{~m}$ from the forest, the net precipitation (throughfall and stemflow) was $904.1 \mathrm{~mm}$ $(83.5 \%)$ of the gross rainfall.

Nutrients - there were significant differences between the concentrations of $\mathrm{K}, \mathrm{Ca}, \mathrm{Mg}$ and $\mathrm{Fe}$ of the litterfall and litter standing crop $(\mathrm{p}<0.01)$. The mean concentrations of $\mathrm{K}, \mathrm{Ca}$ and $\mathrm{Mg}$ of the litterfall were higher than those of the litter standing crop (Tab. 1). In the litterfall, the element concentrations decreased in the order $\mathrm{N}=\mathrm{Ca}>\mathrm{K}>\mathrm{Na}=$ $\mathrm{S}=\mathrm{Zn}>\mathrm{P}>\mathrm{Fe}>\mathrm{Mn}=\mathrm{Hg}>\mathrm{Pb}>\mathrm{Cu}$ while in the litter standing crop of litter it was $\mathrm{N}>\mathrm{Ca}>\mathrm{K}>\mathrm{Zn}>\mathrm{Mg}>\mathrm{S}>$ $\mathrm{Mn}>\mathrm{Fe}>\mathrm{Hg}>\mathrm{Cu}>\mathrm{Pb}$. There were significant differences in the concentrations of $\mathrm{H}^{+}(\mathrm{p}<0.001), \mathrm{K}(\mathrm{p}<0.001), \mathrm{Na}(\mathrm{p}$ $<0.05), \mathrm{Ca}(\mathrm{p}<0.05), \mathrm{Mg}(\mathrm{p}<0.05), \mathrm{Fe}(\mathrm{p}<0.05), \mathrm{Zn}(\mathrm{p}<$ $0.05), \mathrm{Pb}(\mathrm{p}<0.01), \mathrm{NO}_{3}^{-}-\mathrm{N}(\mathrm{p}<0.001), \mathrm{PO}_{4}^{3-}-\mathrm{P}(\mathrm{p}<0.001)$ and $\mathrm{SO}_{4}^{2-}-\mathrm{S}(\mathrm{p}<0.001)$ among the rainwater types (incident rainfall, throughfall, stemflow). Stemflow had the highest mean concentrations of $\mathrm{H}^{+}, \mathrm{K}, \mathrm{Na}, \mathrm{Ca}, \mathrm{Mg}, \mathrm{Fe}, \mathrm{Zn}, \mathrm{NO}_{3}$ $-\mathrm{N}, \mathrm{PO}_{4}{ }^{3}-\mathrm{P}$ and $\mathrm{SO}_{4}{ }^{2-}-\mathrm{S}$, while throughfall had the highest concentrations of $\mathrm{Mn}$ and $\mathrm{Pb}$ (Tab. 1). The concentrations of these elements in both throughfall and stemflow were higher than those of incident precipitation (Tab. 1). There were no significant differences in the concentrations of $\mathrm{Na}$, $\mathrm{Mn}, \mathrm{Cu}, \mathrm{Pb}, \mathrm{Hg}$ and $\mathrm{PO}_{4}^{3-}-\mathrm{P}$ among the rainwater types.

The amounts of different elements deposited in the soil through litterfall and precipitation are presented in Tab. 2. Greater quantities of $\mathrm{Ca}, \mathrm{Mg}, \mathrm{Mn}, \mathrm{Fe}, \mathrm{Zn}, \mathrm{Cu}$ and $\mathrm{N}$ were deposited annually on the forest floor via litterfall while greater quantities of $\mathrm{Na}, \mathrm{K}, \mathrm{Pb}, \mathrm{Hg}, \mathrm{P}$ and $\mathrm{S}$ were deposited via precipitation (Tab. 3). The deposition of these elements in the soil through litterfall decreased in the order $\mathrm{Ca}>\mathrm{N}>$ $\mathrm{K}>\mathrm{Mg}>\mathrm{Na}>\mathrm{S}>\mathrm{Fe}>\mathrm{P}>\mathrm{Mn}>\mathrm{Zn}>\mathrm{Cu}>\mathrm{Hg}>\mathrm{Pb}$ while nutrient reserve in the litter standing crop on the forest floor was in the declining sequence of $\mathrm{N}>\mathrm{Ca}>\mathrm{K}>\mathrm{Fe}>\mathrm{Mg}>$ $\mathrm{P}=\mathrm{Na}>\mathrm{S}>\mathrm{Mn}>\mathrm{Hg}>\mathrm{Pb}>\mathrm{Zn}>\mathrm{Cu}$. Significant differences were observed in the amounts of $\mathrm{Na}(\mathrm{p}<0.001), \mathrm{K}$ ( $\mathrm{p}<0.001), \mathrm{Ca}(\mathrm{p}<0.001), \mathrm{Mg}(\mathrm{p}<0.001), \mathrm{Mn}(\mathrm{p}<0.001)$, Fe ( $\mathrm{p}<0.05), \mathrm{Zn}(\mathrm{p}<0.001), \mathrm{Cu}(\mathrm{p}<0.01), \mathrm{Pb}(\mathrm{p}<0.05)$, $\mathrm{Hg}(\mathrm{p}<0.05), \mathrm{N}(\mathrm{p}<0.01), \mathrm{P}(\mathrm{p}<0.01)$ and $\mathrm{S}(\mathrm{p}<0.01)$ deposited on the forest floor by the litterfall.

\section{Discussion}

The quantity and quality of nutrients returned depends upon the elemental mobility, the internal nutrient resources and the morphological traits of the vegetation during the different stages of nutrient cycling (Gray 1983). In this study, the total litterfall was $9.3 \mathrm{tha}^{-1} \mathrm{yr}^{-1}$ for the period of November 2001 to October 2002. The litterfall value was within the range $\left(7.0-14.1 \mathrm{tha}^{-1} \mathrm{yr}^{-1}\right)$ reported for other West African tropical lowland rainforests (Swift et al. 1981; Songwe et al. 1988, 1995; Muoghalu et al. 1993a; Odiwe \& Muoghalu 2003). The litterfall values also fall within 5.8 to $12.0 \mathrm{tha}^{-1} \mathrm{yr}^{-1}$ reported by Anderson \& Swift (1983) and Proctor (1987) for lowland tropical rain forests. The contributions of the different litterfall fractions (leaf, wood, reproductive parts, trash) to the annual total litterfall was within the range reported for West African Rain forests (Songwe et al. 1988; Odiwe \& Muoghalu 2003, leaf litter 63.6 - 77\%; wood $10-28.3 \%$; reproductive parts $4-12.2 \%$, trash $0.6-9 \%$ ).

The litter standing crop of $3.6 \mathrm{tha}^{-1} \mathrm{yr}^{-1}$ recorded in this study is one of the lowest reported for studies in tropical rain forest: $13.0 \mathrm{t} \mathrm{ha}^{-1}$ (John 1973); $6.9-11.7 \mathrm{t} \mathrm{ha}^{-1}$ (Swift et al. 1981), $2.5-10.5 \mathrm{t} \mathrm{ha}^{-1}$ (Spain 1984), $5.5 \mathrm{t} \mathrm{ha}^{-1}$ (Morellato 1992) and $8.3-9.4 \mathrm{t} \mathrm{ha}^{-1}$ (Odiwe \& Muoghalu 2003). However it falls within $1.7-11.2 \mathrm{t} \mathrm{ha}^{-1}$ reported for lowland tropical rain forest (Anderson \& Swift 1983; Proctor 1987). Also, the percentage contribution by various litter standing crop fractions (leaf, wood, reproductive, trash) to the total litter standing crop is either higher or lower than the range reported for this forest (Odiwe \& Muoghalu 2003) (leaf $42.6-43.4 \%$, wood $34.9-41.5 \%$, reproductive $2.1-4.8 \%$ and trash $13.8-16.9 \%$ ) and a Australian forest (Spain 1984) (leaf $37-46 \%$, wood $40-46 \%$, reproductive parts $1.5-3 \%$ ).

Throughfall estimate of $77 \%$ of annual rainfall of 1078.6 $\mathrm{mm}$ in this study is slightly lower than the range for lowland 
Table 1. Mean monthly nutrient elements concentration of precipitation and litter components in a secondary lowland rain forest at Ile-Ife, Nigeria.

\begin{tabular}{|c|c|c|c|c|c|c|c|c|c|c|c|c|c|c|c|c|c|}
\hline \multirow{2}{*}{ Components } & \multicolumn{17}{|c|}{ Nutrient elements concentration } \\
\hline & $\mathrm{H}^{+}$ & $\mathrm{Na}$ & $\mathrm{K}$ & $\mathrm{Ca}$ & $\mathrm{Mg}$ & $\mathrm{Mn}$ & $\mathrm{Fe}$ & $\mathrm{Zn}$ & $\mathrm{Cu}$ & $\mathrm{Pb}$ & $\mathrm{Hg}$ & $\mathrm{NO}_{3}^{-}-\mathrm{N}$ & $\mathrm{PO}_{4}{ }^{2} \mathrm{P}$ & $\mathrm{SO}_{4}^{2-\mathrm{S}}$ & $\mathrm{N}$ & $\mathrm{P}$ & S \\
\hline \multicolumn{18}{|l|}{ Precipitation } \\
\hline \multirow[t]{2}{*}{ Incident R/Fall (mg L-1 $)$} & $4.77 \times 10^{-7}$ & 3.18 & 1.34 & 0.75 & 0.36 & 0.002 & 0.00 & 0.003 & 0.03 & 0.01 & 0.18 & 1.65 & 0.19 & 1.96 & - & - & - \\
\hline & $\pm 1.12 \times 1^{0-7}$ & \pm 2.12 & \pm 0.41 & \pm 0.18 & \pm 0.04 & \pm 0.08 & \pm 0.00 & \pm 0.002 & \pm 0.02 & \pm 0.006 & \pm 0.06 & \pm 0.54 & \pm 0.09 & \pm 0.23 & - & - & - \\
\hline \multirow[t]{2}{*}{ Throughfall $\left(\mathrm{mg} \mathrm{L}^{-1}\right)$} & $5.4 \times 10^{-7}$ & 5.01 & 30.80 & 1.45 & 1.36 & 0.03 & 0.004 & 0.01 & 0.01 & 0.05 & 0.22 & 0.42 & 0.87 & 4.70 & - & - & - \\
\hline & $\pm 1.35 \times 10^{-7}$ & \pm 3.33 & \pm 6.84 & \pm 0.25 & \pm 0.05 & \pm 0.003 & \pm 0.02 & \pm 0.01 & \pm 0.004 & \pm 0.04 & \pm 0.30 & \pm 0.85 & \pm 0.25 & \pm 0.61 & - & - & - \\
\hline \multirow[t]{2}{*}{ Stemflow (mg L-1) } & $6.41 \times 10^{-7}$ & 4.08 & 38.22 & 2.94 & 2.50 & 0.003 & 0.005 & 0.03 & 0.02 & 0.01 & 0.32 & 6.88 & 1.22 & 4.74 & - & - & - \\
\hline & $\pm 1.79 \times 10^{-7}$ & \pm 2.32 & \pm 7.21 & \pm 1.07 & \pm 1.04 & \pm 0.002 & \pm 0.05 & \pm 0.01 & \pm 0.01 & \pm 0.01 & \pm 0.05 & \pm 1.27 & \pm 0.30 & \pm 0.74 & - & - & - \\
\hline \multicolumn{18}{|l|}{ Litter } \\
\hline \multirow[t]{2}{*}{ Litter Fall (\%) } & - & 0.09 & 0.54 & 1.12 & 0.22 & 0.02 & 0.04 & 0.09 & 0.007 & 0.01 & 0.02 & - & - & - & 1.12 & 0.05 & 0.09 \\
\hline & - & \pm 0.009 & \pm 0.08 & \pm 0.05 & \pm 0.01 & \pm 0.02 & \pm 0.004 & \pm 0.004 & \pm 0.00 & \pm 0.003 & \pm 0.003 & - & - & - & 0.12 & 0.01 & 0.01 \\
\hline \multirow[t]{2}{*}{ Standing Litter Crop (\%) } & - & 0.06 & 0.36 & 0.78 & 0.17 & 0.04 & 0.03 & 0.25 & 0.01 & 0.009 & 0.02 & - & - & - & 1.01 & 0.04 & 0.07 \\
\hline & - & \pm 0.005 & \pm 0.05 & \pm 0.08 & \pm 0.01 & \pm 0.02 & \pm 0.02 & \pm 0.002 & \pm 0.001 & \pm 0.002 & \pm 0.005 & - & - & - & 0.08 & 0.01 & 0.02 \\
\hline
\end{tabular}

$\pm \mathrm{SE}=$ Standard Error

Table 2. Annual deposition $\left(\mathrm{kg} \mathrm{ha}^{-1} \mathrm{yr}^{-1}\right)$ of nutrient elements from precipitation and litter components along with net leaching in a secondary lowland rainforest at Ile-Ife, Nigeria.

\begin{tabular}{|c|c|c|c|c|c|}
\hline Nutrient elements & Incident rainfall & Throughfall & Stemflow & Net removal $\left(\mathrm{kg} \mathrm{ha}^{-1}\right)$ & $\%$ \\
\hline $\mathrm{H}$ & $6.14 \times 10^{-6} \pm 3.01 \times 10^{-7}$ & $5.30 \times 10^{-6} \pm 1.6 \times 10^{-7}$ & $4.47 \times 10^{-7} \pm 1.35 \times 10^{-8}$ & $-3.93 \times 10^{-7} \pm 1.23 \times 10^{-7}$ & -6.4 \\
\hline $\mathrm{Na}$ & $15.73 \pm 0.77$ & $20.81 \pm 1.06$ & $1.82 \pm 0.09$ & $6.9 \pm 0.38$ & 43.9 \\
\hline K & $5.38 \pm 0.18$ & $208.47 \pm 4.20$ & $23.79 \pm 0.56$ & $226.88 \pm 4.76$ & 4217.0 \\
\hline $\mathrm{Ca}$ & $5.80 \pm 0.12$ & $9.84 \pm 0.18$ & $1.37 \pm 0.03$ & $5.41 \pm 0.09$ & 93.3 \\
\hline $\mathrm{Mg}$ & $2.53 \pm 0.05$ & $5.91 \pm 0.18$ & $1.01 \pm 0.03$ & $4.39 \pm 0.16$ & 173.5 \\
\hline $\mathrm{Mn}$ & $0.02 \pm 0.00$ & $0.03 \pm 0.00$ & $0.001 \pm 0.001$ & $0.012 \pm 0.002$ & 55.9 \\
\hline $\mathrm{Fe}$ & $0.00 \pm 0.00$ & $0.08 \pm 0.01$ & $0.003 \pm 0.001$ & $0.083 \pm 0.004$ & 8.3 \\
\hline $\mathrm{Zn}$ & $0.03 \pm 0.00$ & $0.014 \pm 0.001$ & $0.03 \pm 0.003$ & $0.009 \pm 0.002$ & 27.4 \\
\hline $\mathrm{Cu}$ & $0.03 \pm 0.02$ & $0.077 \pm 0.004$ & $0.02 \pm 0.00$ & $-0.22 \pm 0.02$ & -70.9 \\
\hline $\mathrm{Pb}$ & $0.22 \pm 0.02$ & $0.081 \pm 0.004$ & $0.016 \pm 0.001$ & $-0.12 \pm 0.02$ & -55.9 \\
\hline $\mathrm{Hg}$ & $1.22 \pm 0.05$ & $1.96 \pm 0.09$ & $0.22 \pm 0.006$ & $0.79 \pm 0.05$ & 64.5 \\
\hline $\mathrm{NO}_{3}-\mathrm{N}$ & $10.43 \pm 0.03$ & $39.27 \pm 0.76$ & $4.30 \pm 0.1$ & $33.14 \pm 0.55$ & 318.0 \\
\hline $\mathrm{PO}_{4}^{2}-\mathrm{P}$ & $1.74 \pm 0.13$ & $6.11 \pm 0.22$ & $0.87 \pm 0.04$ & $5.24 \pm 0.12$ & 301.2 \\
\hline $\mathrm{SO}_{4}^{2}-\mathrm{S}$ & $20.13 \pm 0.72$ & $37.12 \pm 0.83$ & $2.97 \pm 0.07$ & $19.96 \pm 0.16$ & 99.2 \\
\hline
\end{tabular}

$\pm \mathrm{SE}=$ Standard Error

forests: $78-88 \%$ (Bruijnzeel 1990); Malayan forest, 78.8\% (Manokanran 1979), Bornean and Brunei rain forest, 81 83\% (Sinun et al. 1992) and a plot within this forest, $78.8 \%$ (Muoghalu \& Oakhumen 2000). It is however very similar to 55 to $88 \%$ reported by Brasell \& Sinclair (1983) for an Australian rain forest. This relatively low throughfall value (77\%) reflects the high rainfall interception (17.2\%) of total annual rainfall in this forest during the study period. There were variations in monthly interception of rainfall in the forest with the highest interception in March and September and no interception in May. The high interceptions in March and September coincided with the months with low rainfall and that of July coincided with the month with the highest rainfall. The $6.5 \%$ of the annual precipitation reaching the forest floor from stemflow in this study is higher than 5\% and 5.2\% reported by Eaton et al.(1973) and Muoghalu \& Oakhumen (2000), respectively, but falls within the range of $1-16 \%$ reported by Kittredge (1948).

The significantly higher concentration of $\mathrm{Ca}, \mathrm{K}$ and $\mathrm{Mg}$ in litterfall than in the standing crop of litter is due to the higher rate of leaching of these elements from the decomposing of the standing crop litter into the soil. These elements have been reported to leach from decomposing litter (Gosz et al. 1973, Muoghalu et al. 1993b). The con- 
Table 3. Annual input of nutrient elements by net precipitation and litterfall $\left(\mathrm{Kg} \mathrm{ha}^{-1} \mathrm{yr}^{-1}\right)$ and percentage relative contribution of their components to the input to soil in a secondary lowland rainforest at Ile-Ife, Nigeria.

TF = THROUGHFALL; SF = STEMFLOW; NET PPT = NET PRECIPITATION; LF = LITTER FALL

\begin{tabular}{|c|c|c|c|c|c|c|c|c|c|}
\hline \multirow{2}{*}{ Nutrient element } & \multirow{2}{*}{$\begin{array}{c}\text { Input by } \\
\text { TF }\end{array}$} & \multirow{2}{*}{$\begin{array}{c}\text { Input by } \\
\text { SF }\end{array}$} & \multirow{2}{*}{$\begin{array}{c}\text { Input by } \\
\text { NET PPT }(\mathrm{TF}+\mathrm{SF})\end{array}$} & \multirow{2}{*}{$\begin{array}{c}\text { Input by } \\
\text { LF }\end{array}$} & \multirow{2}{*}{$\begin{array}{c}\text { Total Input } \\
(\mathrm{NET} \text { PPT +LF })\end{array}$} & \multicolumn{4}{|c|}{ Precipitation components } \\
\hline & & & & & & $\mathrm{TF}(\%)$ & $\mathrm{SF}(\%)$ & Total NET PPT(\%) & LF (\%) \\
\hline $\mathrm{Na}$ & 20.81 & 1.82 & 22.63 & 8.28 & 30.91 & 67.3 & 5.9 & 73.2 & 26.8 \\
\hline $\mathrm{K}$ & 208.47 & 23.79 & 232.25 & 57.44 & 289.7 & 71.9 & 8.2 & 80.1 & 19.8 \\
\hline $\mathrm{Ca}$ & 9.84 & 1.37 & 11.27 & 103.78 & 114.99 & 8.6 & 1.2 & 9.8 & 90.2 \\
\hline $\mathrm{Mg}$ & 5.91 & 1.01 & 6.92 & 18.01 & 24.93 & 23.71 & 4.1 & 27.8 & 72.2 \\
\hline $\mathrm{Mn}$ & 0.03 & 0.001 & 0.034 & 1.87 & 1.90 & 1.74 & 0.1 & 1.81 & 98.4 \\
\hline $\mathrm{Fe}$ & 0.08 & 0.003 & 0.08 & 4.22 & 4.30 & 1.86 & 0.1 & 1.93 & 98.1 \\
\hline $\mathrm{Zn}$ & 0.014 & 0.029 & 0.04 & 0.66 & 0.70 & 2.04 & 4.1 & 6.18 & 94.3 \\
\hline $\mathrm{Cu}$ & 0.07 & 0.014 & 0.092 & 0.28 & 0.37 & 20.9 & 3.8 & 24.7 & 75.5. \\
\hline $\mathrm{Pb}$ & 0.08 & 0.016 & 0.097 & 0.01 & 0.11 & 73.6 & 14.5 & 88.1 & 9.01 \\
\hline $\mathrm{Hg}$ & 1.96 & 0.22 & 2.18 & 0.02 & 2.2 & 89.1 & 10.0 & 99.1 & 0.91 \\
\hline Nitrogen & 39.27 & 4.30 & 43.57 & 101.80 & 145.37 & 27.0 & 2.9 & 29.9 & 70.0 \\
\hline Phosphorus & 6.11 & 0.87 & 6.98 & 4.05 & 11.03 & 55.4 & 7.89 & 63.8 & 36.7 \\
\hline Sulphur & 37.12 & 2.97 & 40.09 & 0.61 & 47.61 & 77.9 & 6.24 & 84.2 & 15.8 \\
\hline
\end{tabular}

centrations of the various elements in the net precipitation (stemflow, throughfall) were higher than those of incident precipitation in this study. This indicates the alteration of precipitation when passing through the forest canopy results in increased concentrations of these elements in net precipitation compared to incident precipitation. Similar findings have been reported for this forest (Muoghalu \& Oakhumen 2002) and other tropical forests (Asbury et al. 1994; Strigel et al. 1994; McDowell 1998). Enrichment of elements in the net precipitation has been attributed to dissolution and washout of atmospheric materials deposited on the canopy (Eaton et al. 1973; Parker 1983) or exchanges between rainfall and elements in internal plant parts (Marques \& Ranger 1997; McDowell 1998).

Annual inputs of elements in this forest via litterfall show that the values fall within the range of values for reported elements for other tropical rain forest. There was seasonal deposition of these elements with the highest amounts of $\mathrm{Na}, \mathrm{Mn}, \mathrm{Zn}, \mathrm{P}$ and $\mathrm{S}$ deposited during the wet season while the highest amounts of $\mathrm{K}, \mathrm{Ca}, \mathrm{Mg}, \mathrm{Fe}, \mathrm{Cu}, \mathrm{Pb}, \mathrm{Hg}$ and $\mathrm{N}$ were deposited during the dry season. The turnover coefficients of these nutrients indicated that $\mathrm{K}\left(3.9 \mathrm{yr}^{-1}\right)$ is the most rapidly recycled element while $\mathrm{Fe}\left(0.4 \mathrm{yr}^{-1}\right)$ and $\mathrm{S}(0.7$ $\left.\mathrm{yr}^{-1}\right)$ are the least recycled elements. Nutrient deposition via precipitation in the forest shows that $\mathrm{K}$ (potassium) is deposited in the largest quantity in the forest through this pathway. Similar results have been reported for this forest (Muoghalu \& Oakhumen 2000) and other tropical forests (Strigel et al. 1994; McDowell 1998). Net retention of ions by the canopy is typically estimated by comparing measured estimates of deposition in incident precipitation to fluxes in throughfall and stemflow. In this study, there is a clear pattern of retention of $\mathrm{H}^{+}, \mathrm{Cu}$ and $\mathrm{Pb}$ ions in the canopy while other ions are leached from the canopy; the most leached were $\mathrm{K}, \mathrm{Ca}, \mathrm{Mg}, \mathrm{NO}_{3}^{-}-\mathrm{N}, \mathrm{PO}_{4}^{3-}-\mathrm{P}^{2}$ and $\mathrm{SO}_{4}{ }^{2-}-\mathrm{S}$ ( Tab. 3). Similar retention of hydrogen ions by forest canopies has been reported (Eaton et al. 1973; Clark et al. 1998; Muoghalu 1999) and net leaching of base and sulphate ions (Sinun et al. 1992; Strigel et al. 1994; McDowell 1998; Burghouts et al. 1998; Muoghalu 1999; Muoghalu \& Oakhumen 2000). The results confirm the assertion by Muoghalu (2003) that micronutrients are cycled mainly through litterfall in tropical rainforests.

The study shows that litterfall is the main pathway for cycling calcium, copper, iron, magnesium, manganese, nitrogen and zinc while net precipitation (stemflow, throughfall) is the main pathway for cycling lead, mercury, phosphorus, potassium, sodium and sulphur in the forest. Copper, hydrogen and lead ions were retained and the other elements, especially the base ions, were leached from the forest canopy as precipitation passed through the forest. These findings have added more value to the understanding of nutrient cycling in, and the management of, tropical rain forests because the amount of nutrients returned to forest floor is important in maintaining the fertility and productivity of forest ecosystems in humid tropical regions where soils are often low in fertility.

\section{References}

Allen, S.E.; Grinshaw, H.M.; Parkinson, J.A. \& Quarmby. 1974. Chemical Analysis of Ecological Materials. Oxford, Blackwell Scientific Publications.

Anderson, J.M. \& Swift, M.J. 1983. Decomposition in tropical forests. Pp. 287-309. In: Sutton, S.L., Whitmore, T.C. and Chadwick, A.C. (Eds.). Tropical Rain forest: Ecology and Management. Oxford, Blackwell Publications. 
Arunachalam, A.; Arunachalam, K.M.; Prindey, H.N. \& Tripath, R.S. 1998. Fine litterfall and nutrient dynamics during forest regrowth in the humid subtropics of North-eastern India. Forest Ecology and Management 110: 209-219.

Asbury, C.E.; McDowell, K.H.; Trindad - Pizarro, R. \& Berries, S. 1994. Solute deposition from cloud water to the canopy of a Puerto Rican montane forest. Atmospheric Environment 8: 1773-1780.

Awokoya, M.O. 2003. Biomass nutrient content and species composition of herbs in Nigerian secondary rainforest. An unpublished B.Sc Thesis, Obafemi Awolowo University, Ile -Ife.

Ayodele, O.J. 1986. Phosphorous availability in savanna soils of Western Nigeria. Tropical Agriculture (Trinidad) 63: 297-300

Banaszak, K.T. 1975. Relative throughfall of all enrichment by biological and aerosol derived materials in loblolly Pines. Miss. Water Research Institute Mississippi State University, PB - 245-258/9ST. Nat. Tech. Info centre. Virginia, Spring Field.

Brasell, H.M \& Sinclair D.R. 1983. Elements returned to forests floor in two rainforest and three plantation plots in tropical Australia. Journal of Ecology 71: 367-378.

Brasell, H.M.; Unwin, G.L. \& Stocker, G. 1980. The quantity, temporal and distribution of mineral element content of litter fall in two forest types at two sites in Australia. Journal of Ecology 68: 123-129.

Brinkmann, W.L.F. 1985. Studies on hydrobiogeochemistry of a tropical lowland forest system. Geojournal 11: 89-101.

Brown, S. \& Lugo, A.E. 1990. Tropical secondary forests. Journal of Tropical Ecology 6: 1-32.

Bruijnzeel, L.A. 1990. Nutrient input-output budgets to tropical forest ecosystems: a review. Journal of Tropical Ecology 7: 1-24.

Burghouts, T.B.A.; Van Straalen, N.M. \& Bruijnzeel. L.A. 1998. Spatial heterogeneity of element and litter turnover in a Bornean rainforest. Journal of Tropical Ecology 14: 477-505.

Carlisle, A.; Brown, A.H.F. \& White, E.J. 1966. The organic matter and nutrient elements in the precipitation beneath a sessile oak (Quercus petraea) canopy. Journal of Ecology 54: 87-98.

Clark, K.H.; Nadkarni, N.M.; Schaeffer. D. \& Gholz, H.L. 1998. Atmospheric deposition and net retention of ions by the canopy in a tropical montane forest, Montverde, Costa Rica. Journal of Tropical Ecology 14: 27-45.

Congdon, R.A. \& Herborn, J.L. 1993. Ecosystem dynamics at disturbed and undisturbed sites in North Queensland Wet Tropical Rainforest. I. Floristic composition, climate and soil chemistry. Journal of Tropical Ecology 9: 349-363.

Congdon, R.A. \& Lamb, D. 1990. Essential nutrient cycles. Pp. 105-113. In: Webb, L.J and Kikkawa, L.(Eds). Australian tropical rainforests. Melbourne, Science-value-meaning-CSIRO.

Duncan, E.R. 1974. Weather Information from the University of Ife, Faculty of Agriculture Research Bulletin. No 2 University of Ife Press, Ile-Ife.

Eaton, J.S.; Likens, G.G. \& Bormann, F.H. 1973. Throughfall and stemflow chemistry in a Northern hardwood forest. Journal of Ecology 61: 495-508.

FAO/UNESCO. 1974. World soil classification. Pp. 59. In: Legend to Soil Map of the World. Volume 1. Paris, UNESCO.

Gosz. J.R.; Likens, G.E. \& Bormann, F.H. 1973. Nutrient release from decomposing leaf and branch litter in the Hubbard book forest, New Hampshire. Ecological Monographs 43:173-191.

Gosz, J.R.; Likens, G.E. \& Bormann, F.H. 1976. Organic matter and nutrient dynamics of the forest and food floor in the his board book forest. Oecologia 22: 305-320.

Gray, J.T. 1983. Nutrient use by evergreen and deciduous shrubs in southern California. I. Community nutrient cycling and nutrient use efficiency. Journal of Ecology 71: 21-41.

Hall J.B. 1969. The vegetation of Ile-Ife. University of Ife herbarium, Bulletin I.

Herborn, J.L. \& Congdon, R.A. 1998. Ecosystem dynamics at disturbed and undisturbed sites in North Queensland Wet tropical rainforest. 11l. Nutrient returns to the forest floor through litter fall. Journal of Ecology 14: 219-229.

Isichei, A.O.; Ekeleme, F \& Jimoh, B.A. 1986. Changes in a secondary forest in South Western Nigeria following a ground fire. Journal of Tropical Ecology 2: 249-256
Kittredge, J. 1948. Forest Influence. New York, McGraw-Hill.

Likens, G.E.; Bormann, F.H.; Pierce, R.W.; Eaton, J.S. \& Johnson, N.M. 1977. Biogeochemistry of a forested ecosystem. New York, SpringerVerlag.

Lindberg S.E.; Harriss, R.C.; Turner, R.R.; Shrimer, D.S. \& Huff, D.D. 1979. Mechanisms and Rates of Atmospheric Deposition of Selected Trace Elements and Sulfate to a Deciduous Forest Watershed. Oak ridge National laboratory. Environmental sciences division published No. 1299 ORNL/TM-6674.

Liu, W.; Fox, J.E.D. \& Xu, Z. 2002. Nutrient flux in bulk precipitation throughfall and stemflow in montane subtropical moist forest on Ailao Mountains in Yunnan, S.W. China. Journal of Tropical Ecology 18: $527-548$

Manokanran, N. 1979. Stemflow, throughfall and rainfall interception in a lowland tropical rainforest in Peninsular Malaysian. Malayan Forester 42: 174-201.

Marques, R. \& Rangers, J. 1997. Nutrient dynamics in a chronosequence of douglas - fir (Pseudotsuga menziesii (Mirbo) Franco) stands on the Beaujolais Mounts (Franco) I: Qualitative approach. Forest Ecology and Management 91: 255-277.

McDowell, N.H. 1998. Internal nutrient fluxes in a Puerto Rican rainforest. Journal of Tropical Ecology 14: 521-536.

Moore, P.O. \& Chapman, S.B. 1986. Methods in Plant Ecology. Oxford, Blackwell Scientific Publications.

Morellato, L.P.C. 1992. Nutrient cycling in two southeast Brazilian forests. I. Litterfall and litter standing crop. Journal of Tropical Ecology 8: 205-215.

Muoghalu, J.I. \& Oakhumen, A. 2000. Nutrient content of incident rainfall throughfall and stemflow in a Nigerian secondary lowland rainforest. Applied Vegetation Science 3: 181-188.

Muoghalu, J.I. 1999. Chloride, hydrogen and sulphate ions deposition via precipitation at Ile-Ife, Nigeria. Nigerian Journal of Botany 12 : 121-129.

Muoghalu, J.I. 2003. Contributions of throughfall, stemflow and litter fall to nutrient cycling in a secondary lowland rainforest in Ile-Ife, Nigeria. Journal of Tropical Forest Science 15: 339-410.

Muoghalu, J.I.; Akanni, S.O. \& Eretan O.O. 1993a. Litterfall and nutrient dynamics in a Nigerian rainforest seven years after a ground fire. Journal of Vegetation Science 4: 303-328.

Muoghalu, J.I.; Oladotun, S.T. \& Bakare, A.O. 1993b. Woody branch litter decomposition and inorganic element dynamics in a Nigerian secondary rainforest. Nigerian Journal of Botany 6: 115-128.

Odiwe, A.I. \& Muoghalu, J.I. 2003. Litterfall dynamics and forest floor litter as influenced by fire in a secondary lowland rainforest in Nigeria. Tropical Ecology 44: 241-249.

Onochie, C.F.A. 1979. The Nigerian rainforest ecosystem: an overview. Pp 1-13. In: Okali, D.U.U. (Eds.). The Nigerian Rainforest Ecosystem. Proceedings of the M.A.N and Biosphere on the Nigeria Rainforest. University of Ibadan, 1978. Ibadan, Nigeria National MAB committee.

Parker G.G. 1983. Throughfall and stemflow in the forest mineral cycle. Advances in Ecological Research 13: 57-133.

Pathak, P.C. \& Singh, J.S. 1984. Nutrients in precipitation components for pine and oak forests in Kumaun, Himalaya. Tellus 36: 44-49.

Prebble, R.E. \& Stirk, G.B. 1980. Throughfall and stemflow on silver leaf iron bark (Eucalyptus melanophaloia) trees. Australian Journal of Ecology 5: 419-427.

Proctor, J.; Anderson, J.M.; Fogden, S.C.L. \& Vallack, H.N. 1983. Ecological studies in four constrasting lowland rainforests in Gunung Mulu National Park, Sarawak. 1l. Litter fall, litter standing crop and preliminary observations on herbivory. Journal of Ecology 71: 261-283.

Proctor, J. 1987. Nutrients cycling in primary and old secondary, rainforests. Applied Geography 7: 135-152.

SAS, 1999. Statistical methods. Statistical analysis system institute inc. Cary North Carolina.

Sinun, W.; Wong, W.W.; Douglas, I. \& Spencer, T. 1992. Throughfall, stemflow, overland flow and throughflow on the Ulu Segama Rainforest, Sabah Malaysia, Phil. Trans. Royal Society London Service B 335: 389-395 
Songwe, N.C.; Faseheun, F.G \& Okali, D.U.U. 1988. Litterfall and productivity in a tropical rainforest, Southern Bakundu forest reserve, Cameroon. Journal of Tropical Ecology 4: 25-37.

Songwe, N.C.; Okali, D.U.U. \& Fasheun, F.E. 1995. Litter decomposition and nutrient release in a tropical rainforest, southern Bakundu forest reserve, Cameroon. Journal of Tropical Ecology 11: 333-350.

Spain, A.V. 1984. Litterfall and the standing crop of litter in three tropical Australian Rainforests. Journal of Ecology 72: 947-961.

Strigel, G.; Ruhiyat D.; Prayltimo, D. \& Sarmina, S. 1994. Nutrient input by rainfall into secondary roots in East Kalimantan, Indonesia. Journal of Ecology 10: 285-288.

Swift, M.J.; Russell-Smith A. \& Perfect, I.J. 1981. Decomposition and mineral nutrient dynamics of plant litter in a regenerating bush fallow in sub humid tropical Nigeria. Journal of Ecology 69: 981-995.

Tel. D.A. \& Rao, P.V. 1982. Automated analysis and semi automated Methods for soil and Plant Analysis. Manual series. No 7. Ibadan, International Institute of Tropical Agriculture.
USDA. 1975. Soil Taxonomy. Agricultural Hand book 436. Washington, US Department of Agriculture.

Vitousek, P.M. \& Sanford, R.L.J. 1986. Nutrient cycling in moist tropical forest. Annual Review of Ecology and Systematics 17: 137-167.

Vitousek, P.M. 1982. Nutrient cycling and nutrient use efficiency. American Nature 119: 553-572.

Waring, R.H. \& Schelsinger, W.H. 1985. Forest Ecosystems:Concepts and Management. Orlando, Academic press.

White, F. 1983. The vegetation of Africa-a descriptive memoir to accompany the UNESO/AETFAT UNSO Vegetation, Map of Africa. Paris, UNESCO.

Wilson, R.C. 1922. The Geology of the Western Railway Section 1. Bulletin No 2. Geological Survey of Nigeria.

Zar, J.H. 1984. Biostatistical analysis. 2nd ed. Englewood cliffs, New Jersy Prentice - Hall.

Zinke, P.J. 1962. The patterns of influence of individual forest trees on soil properties. Ecology 43: 130-133. 